\title{
Is Reconstruction of the Sella Necessary to Prevent Optic Chiasm Prolapse and Cerebrospinal Fluid Leakage Following Endoscopic Resection of Pituitary Macroadenomas?
}

\author{
Marc L. Otten, MD \\ Thomas Jefferson University \\ Mary Petrone, BA \\ Thomas Jefferson University \\ Gurston G. Nyquist, MD \\ Thomas Jefferson University \\ Marc Rosen MD \\ Thomas Jefferson University

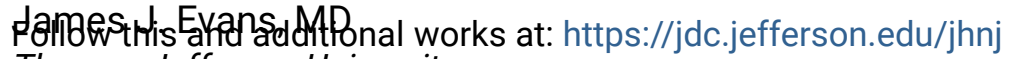 \\ Thepas Jefferson University access to this document benefits you
}

\author{
See nextpage for additional authors \\ Otten, MD, Marc L.; Petrone, BA, Mary; Nyquist, MD, Gurston G.; Rosen, Marc MD; Evans, MD, James J.; and \\ Farrell, MD, Christopher J (2015) "Is Reconstruction of the Sella Necessary to Prevent Optic Chiasm \\ Prolapse and Cerebrospinal Fluid Leakage Following Endoscopic Resection of Pituitary \\ Macroadenomas?," JHN Journal: Vol. 10 : Iss. 2 , Article 4. \\ DOI: https://doi.org/10.29046/JHNJ.010.2.002 \\ Available at: https://jdc.jefferson.edu/jhnj/vol10/iss2/4
}

This Article is brought to you for free and open access by the Jefferson Digital Commons. The Jefferson Digital Commons is a service of Thomas Jefferson University's Center for Teaching and Learning (CTL). The Commons is a showcase for Jefferson books and journals, peer-reviewed scholarly publications, unique historical collections from the University archives, and teaching tools. The Jefferson Digital Commons allows researchers and interested readers anywhere in the world to learn about and keep up to date with Jefferson scholarship. This article has been accepted for inclusion in JHN Journal by an authorized administrator of the Jefferson Digital Commons. For more information, please contact: JeffersonDigitalCommons@jefferson.edu. 
Is Reconstruction of the Sella Necessary to Prevent Optic Chiasm Prolapse and Cerebrospinal Fluid Leakage Following Endoscopic Resection of Pituitary

Macroadenomas?

\section{Authors}

Marc L. Otten, MD; Mary Petrone, BA; Gurston G. Nyquist, MD; Marc Rosen MD; James J. Evans, MD; and Christopher J Farrell, MD 


\section{Is Reconstruction of the Sella Necessary to Prevent Optic Chiasm Prolapse and Cerebrospinal Fluid Leakage Following Endoscopic Resection of Pituitary Macroadenomas?}

Marc L. Otten, MD1; Mary Petrone, BA2; Gurston G. Nyquist, MD²; $^{2}$

Marc R. Rosen, MD2,3; James J. Evans, MD 2,3; Christopher J. Farrell, MD ${ }^{3}$

${ }^{1}$ Department of Neurological Surgery, Columbia University, New York, NY

2Department of Otolaryngology, Thomas Jefferson University, Philadelphia, PA

${ }^{3}$ Department of Neurological Surgery, Thomas Jefferson University, Philadelphia, PA

\section{INTRODUCTION}

Visual compromise is a common presentation of pituitary macroadenomas and is related to direct optic nerve and chiasm compression. Although the extent of visual recovery following treatment depends on the duration and severity of the visual compromise, the majority of patients experience gradual improvement in their vision. Delayed visual deterioration following treatment is typically related to either tumor recurrence or radiation-induced optic neuropathy, although visual worsening due to prolapse of the optic apparatus into a secondary empty sella has rarely been reported. In 1968, Guiot reported the first a case of reversible visual deterioration associated with optic chiasm prolapse following resection of a large pituitary macroadenoma (Guiot). Based on their observations, Guiot and collaborators recommended that a "prop" be placed in the sella at the time of transsphenoidal pituitary adenoma resection to prevent progressive herniation of the optic structures. Similarly, Hardy coined the term "preventive chiasmopexy" to describe filling of the sella cavity with autologous tissue such as muscle or fat following resection of large tumors to prevent this herniation phenomenon. While optic chiasm prolapse with associated visual deterioration appears to represent a rare occurrence, its true incidence and pathophysiological basis remain uncertain. Reconstruction of the sella with autologous tissues is also widely employed as a means to prevent postoperative cerebrospinal fluid leakage with these tissues typically harvested from a secondary operative site such as the abdomen. Although not frequently reported in the pituitary literature, complications of abdominal fat graft harvest include hematoma and seroma formation as well as infection with an incidence ranging from 1-7\%. At our institution, we do not routinely perform dural reconstruction following transsphenoidal resection of pituitary macroadenomas using adipose tissue to prevent cerebrospinal fluid leakage or optic chiasm prolapse. In this study, we sought to determine the incidence of optic chiasm prolapse into the sellar defect by determining the radiographic position of the optic chiasm following surgery and incidence of delayed visual deterioration.

\section{METHODS}

A retrospective review was performed for 100 consecutive patients with pituitary macroadenomas who underwent transsphenoidal resection with postoperative clinical and radiographic data greater than 6 months from the date of initial surgery (Table 1). The position of the optic chiasm was determined on sagittal MRI and defined as the distance above a line constructed between the superior aspect of the tuberculum sellae and the dorsum sellae (Figure 1). The position of the optic chiasm was compared between the preoperative MRI and the available MRI most distant from the date of surgery. Visual data was obtained from the clinical record. Dural closure was performed using a synthetic dural substitute placed as an inlay graft under the dural defect and supplemented with a thin layer of dural sealant (Tissee ${ }^{\circledR}$, Baxter Healthcare; Duraseal ${ }^{\circledR}$, Covidien)

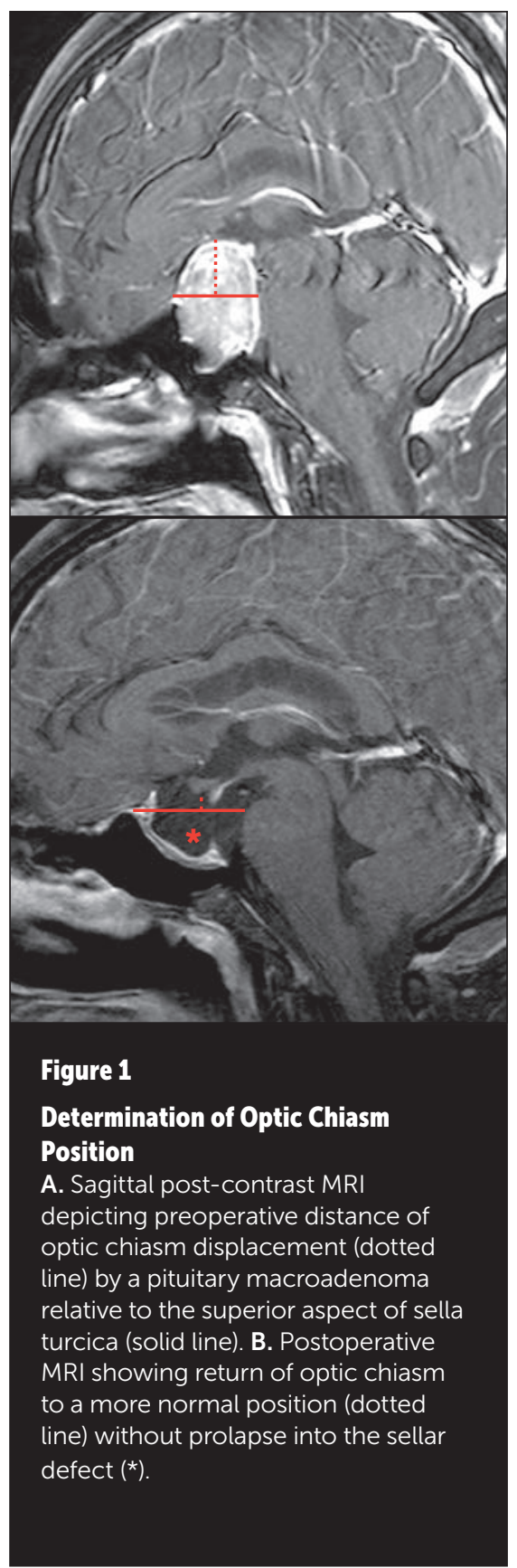




\begin{tabular}{|l|c|}
\hline \multicolumn{2}{|l|}{ Table 1: Demographics } \\
\hline Male & 56 \\
\hline Female & 44 \\
\hline Average Age & $54 \pm$ 13 years (range 22-80) \\
\hline Tumor type & \multicolumn{2}{|c|}{} \\
\hline Non-secretory Adenoma & 26 \\
\hline Prolactinoma & 12 \\
\hline Growth Hormone Secreting Adenoma & \\
\hline CSF leak & 17 \\
\hline Intraoperative & 0 \\
\hline Postoperative & \multicolumn{2}{|c|}{} \\
\hline
\end{tabular}

\begin{tabular}{|c|c|c|c|}
\hline \multicolumn{4}{|c|}{ Figure 2: Optic Chiasm Position } \\
\hline & Total & $\begin{array}{l}\text { No preoperative } \\
\text { Visual loss }\end{array}$ & $\begin{array}{l}\text { Preoperative } \\
\text { Visual loss }\end{array}$ \\
\hline Average tumor size (mm) & $24.9 \pm 10.2$ & $18.5 \pm 6.5$ & $29.2 \pm 10.1$ \\
\hline $\begin{array}{l}\text { Average preoperative } \\
\text { displacement of } \mathrm{OC}(\mathrm{mm})\end{array}$ & $9.0 \pm 5.9$ & $6.2 \pm 3.6$ & $11.2 \pm 6.7$ \\
\hline $\begin{array}{l}\text { Postoperative position of } \\
O C(\mathrm{~mm})\end{array}$ & $3.0 \pm 2.0$ & $3.1 \pm 2.0$ & $2.6 \pm 1.7$ \\
\hline
\end{tabular}

endoscopic transsphenoidal resection of pathologically demonstrated pituitary macroadenomas without packing of the tumor resection cavity using synthetic or autologous materials. Preoperative MRI demonstrated the presence of a macroadenoma with suprasellar extension in all cases with a mean tumor height dimension of $24.9 \mathrm{~mm}( \pm 10.2)$ (Table 2). The average position of the optic chiasm preoperatively was $9.0 \mathrm{~mm}$ $( \pm 5.9)$ above the superior aspect of the sella turcica. The mean time between the date of surgery and postoperative MRI was 422 days $( \pm 239)$. No patient reported delayed visual deterioration postoperatively and the mean position of the optic chiasm on postoperative MRI was $3.0 \mathrm{~mm}( \pm 2.0)$ above the superior aspect of the sella. Despite the presence of a large intrasellar tumor resection cavity in all cases, inferior prolapse of the optic chiasm was observed on delayed postoperative MRI in only $1 / 100$ cases and not associated with visual impairment.
Preoperative evaluations revealed that 57 patients complained of visual loss prior to surgery. Tumors reported to cause visual loss were significantly larger (29.2 $+/-10.0 \mathrm{~mm}$ ) than tumors that did not inhibit vision ( $18.5+/-6.5 \mathrm{~mm}, \mathrm{p}<0.0001)$, and the amount they displaced the optic chiasm (11.2 +/- 6.7mm) differed significantly from the amount of displacement caused by tumors that did not affect vision $(6.2+/-3.6 \mathrm{~mm}, \mathrm{p}<0.0001)$. Of the patients with initial visual loss, 48 (84.2\%) reported an improvement in their vision after surgery while 7 (12.28\%) reported no change in their visual status. The amount of postoperative displacement of the optic chiasm in patients whose vision did not change postoperatively was not significantly different from that of patients who experienced visual improvement after surgery. At follow-up, no change in visual status was reported for any of the patients who were without visual deficiencies before surgery. No delayed visual worsening throughout the study period was observed. No patient developed a postoperative cerebrospinal fluid (CSF) leak, though 17 experienced intraoperative leaks.

\section{DISCUSSION}

This study demonstrates that inferior prolapse of the optic apparatus into the sellar defect following transsphenoidal pituitary macroadenoma resection represents an extremely rare occurrence and placement of an intrasellar "prop" consisting of harvested autologous tissue is not necessary to achieve stable visual recovery. Our success, combined with the rarity of visual loss secondary to optic apparatus prolapse, lead us to reason that the risks of autograft outweigh its possible benefits.

\section{Pathophysiology of delayed visual loss}

Since Guiot first introduced the concept of a "prop" to prevent delayed visual changes after macroadenoma resection, several groups have tested theories regarding the pathophysiology of this complication. Chiasmal scarring was present in the fifteen surgical cases in the literature (Czech 1999, Decker 1977, Fischer 1994, Thome 2004), and is mostly accompanied by displacement of the chiasm and optic nerves into the sella. In our practice, we have seen several cases of delayed visual deterioration secondary to shrinkage of giant pituitary prolactinomas with optic chiasm prolapse following prolonged dopamine agonist therapy (Figure 2). In all cases, the visual worsening has stabilized an ultimately improved following temporary cessation of dopamine agonist therapy and slight regrowth of the prolactinoma and return of the chiasm to a more normal position, further suggesting that these invasive tumors may become tethered to the chiasm and pull the optic apparatus into the sella. Alternative proposed etiologies for delayed visual loss following pituitary tumor resection include vascular compression, scarring and radiation effects [(Thome 2004) (Lee, 1983) (Adams 1988)].

\section{Risks of autologous grafting}

Autologous grafting has long been part of closure techniques for skull base 
surgery, but it comes with some risks. These include an extra incision, with inherent risk of infection at donor or recipient sites, seroma formation, and donor site dehiscence. Taha et al. report on 10 complications in 974 cases in which autologous fat graft was used to reconstruct the skull base. They report this $1 \%$ rate of early and late complications secondary to fat necrosis, including sterile liquefied fat fistula, CSF leakage, and lipoid meningitis (Taha 2011). Sade adds that autologous graft can mimic tumor on imaging, making the identification of recurrence more difficult. This contrasts with surgical and fibrin glues, which produce a thin rim of hypointensity, which is distinctive from recurrence on MRI (Sade 2006). Additionally, packing the sella can cause complications secondary to mass effect, which would compromise the decompressive goal of macroadenoma resection (Slavin 1993).

\section{CONCLUSION}

These data confirm that reconstruction of the sellar defect is not necessary to prevent optic chiasm prolapse following transsphenoidal resection of a pituitary macroadenoma. Furthermore, harvest of autologous tissues such as adipose tissue is not necessary for prevention of postoperative CSF leakage, even when an intraoperative CSF leak is experienced.

\section{REFERENCES}

1. Adams CB (1988) The management of pituitary tumours and postoperative visual deterioration. Acta Neurochir (Wien) 94: 103-116

2. Bangash $\mathrm{MH}$, Clarke DB, Holness RO. Brain \& chiasmal herniations into sella after medical treatment of prolactinoma. Can J Neurol Sci. 2006 May;33(2):240-2.

3. Barzaghi LR, Losa M, Giovanelli M, Mortini P. Complications of transsphenoidal surgery in patients with pituitary adenoma: experience at a single centre. Acta Neurochir (Wien). 2007;149(9):877-85; discussion 885-6. Epub 2007 Jul 9.

4. Bjerre P, Gyldensted C, Riishede J, et al: The empty sella and pituitary adenomas. A theory on the causal relationship. Acta Neurol Scand 66:82-92, 1982

5. Busch W: [Morphology of sella turcica and its relation to the pituitary gland]. Virchows Arch 320:437-58, 1951

6. Czech T,Wolfsberger S, Reitner A, Gorzer H (1999) Delayed visual deterioration after surgery for pituitary adenoma. Acta Neurochir (Wien) 141: 45-51
7. Decker RE, Carras R (1977) Transsphenoidal chiasmapexy for correction of posthypophysectomy traction syndrome of optic chiasm. Case report. J Neurosurg 46: 527-529

8. Dhanwal DK, Sharma AK. Brain and optic chiasmal herniations into sella after cabergoline therapy of giant prolactinoma. Pituitary. 2011 Dec;14(4):384-7

9. Dorotheo EU, Tang RA, Bahrani HM Schiffman JS, Bhatti MT, Lewis SB. Her vision was tied down. Surv Ophthalmol. 2005 Nov-Dec;50(6):588-97.

10. Guinto G, del Valle R, Nishimura E, et al: Primary empty sella syndrome: the role of visual system herniation. Surg Neurol 58:42-7; discussion 47-48, 2002

11. Guiot G, Derome P (1976) Surgical problems of pituitary adenomas. In: KrayenbuÈ hl H (ed). Advances and technical standards in neurosurgery, Vol. 3. Springer-Verlag, Wien, pp 1-33

12. Guiot G, Derome P, Demailly P, Hertzog E (1968) Complication inattendue de l'exeÂreÁse compleÁte de volumineux adeÂnomes hypophysaires. Rev Neurol 118: 164-167

13. Holsgrove D, Leach P, Herwadkar A Gnanalingham KK. Visual field deficit due to downward displacement of optic chiasm. Acta Neurochir (Wien). 2009 Aug;151(8):995-7

14. Laws ER, Fode NC, Redmond MJ (1985) Transsphenoidal surgery following unsuccessful prior therapy. An assessment of benefits and risks in 158 patients. J Neurosurg 63: $823-829$

15. Lee FK, Richter HA, Tsai FY: Secondary empty sella syndrome. Acta Radiol 347(Suppl):31326, 1976

16. Lee FK. Ischemic chiasma syndrome. AJNR 1983; 4:777-780

17. Marcos L, De Luis DA, Botella I, et al: Tumour shrinkage and chiasmal herniation after successful cabergoline treatment for a macroprolactinoma. Clin Endocrinol (Oxf) 54 126-7, 2001

18. Olson DR, Guiot G, Derome P (1972) The symptomatic empty sella. Prevention and correction via the transsphenoidal approach. J Neurosurg 37: 533-537

19. Raverot G, Jacob M, Jouanneau E, Delemer B, Vighetto A, Pugeat M, Borson-Chazot F. Secondary deterioration of visual field during cabergoline treatment for macroprolactinoma. Clin Endocrinol (Oxf). 2009 Apr;70(4):588-92

20. Sade B, Mohr G, Frenkiel S. Management of intra-operative cerebrospinal fluid leak in transnasal transsphenoidal pituitary microsurgery: use of post-operative lumbar drain and sellar reconstruction without fat packing Acta Neurochir (Wien). 2006 Jan;148(1):13-8; discussion 18-9. Epub 2005 Nov 21

21. Slavin ML, Lam BL, Decker RE, Schatz NJ, Glaser JL, Reynolds MG (1993) Chiasmal compression from fat packing after transsphenoidal resection of intrasellar tumor in two patients. Am J Ophthalmol 115: 368-371
22. Steiner E, Knosp E, Herold CJ, et al (1992) Pituitary Adenomas: Findings of Postoperative MR Imaging. Radiology 185: 521-527

23. Taha AN, Almefty R, Pravdenkova S, Al-Mefty $O$. Sequelae of autologous fat graft used for reconstruction in skull base surgery. World Neurosurg. 2011 May-Jun;75(5-6):692-5. doi: 10.1016/j.wneu.2011.01.023.

24. Taxel $P$, Waitzman DM, Harrington JF, et al (1996) Chiasmal herniation as a complication of Bromocriptine therapy. J NeuroOphthalmol 16: 252-257

25. Welch K, Stears JC (1971) Chiasmapexy for the correction of traction on the optic nerves and chiasm associated with their descent into an empty sella turcica. Case report. J Neurosurg 35: 760-764 